has been given to methods of representation of the course of hydrogenation of mixed glycerides.

Many readers may be disappointed to find that the technology of fat-hardening is dealt with in seventeen pages and the production of hydrogen, one of the essentials in the process, is inadequately covered in a book with such a title; and no assessment of the principal industrial methods has been attempted.

Despite its limitations there is much to be learnt from this book. The hundred and twenty pages on hydrogenation contain a valuable original approach to the fundamental chemistry of the hydrogenation of oils and fats, and for this reason Prof. Waterman's book will be of interest to advanced students and to chemists and technologists in the fatty oils industries. H. JASPERSON

\section{MINERAL NUTRITION OF PLANTS}

Mineral Nutrition of Plants

Edited by Emil Truog. (Published in celebration of the Hundredth Anniversary of the Founding of the University of Wisconsin.) Pp. xiii +469 . (Madison : University of Wisconsin Press, 1951.) 6 dollars.

T HIS volume, published under the nominal editorship of Prof. E. Truog, comprises eighteen contributions by different authors, based on papers communicated at a symposium held in the University of Wisconsin. The main object of the symposium was to provide an opportunity for the exposition of the latest views on mineral nutrition, for the mutual benefit of those concerned in the investigation of particular aspects, and for the guidance of those engaged in the practical cultivation of plants, in fertilizer manufacture and in food industries.

Since potential purchasers of a specialist treatise of this type are to some extent influenced by the reputation of the contributors, it is appropriate that these should be indicated in this notice. They are C. E. Kellogg and A. C. Orvedal, E. Truog, C. E. Marshall, R. Overstreet and L. A. Dean, H. Jenny; J. B. Page and G. B. Bodman, A. G. Norman, T. C. Broyer, H. Burström, O. Biddulph, D. Boynton, J. B. Hester, D. I. Arnon, W. F. Loehwing, R. A. Steinberg, R. B. Withrow, C. H. Wadleigh and L. A. Richards, and H. F. Clements. It is at once clear that there assembled at Madison as distinguished a group of mineral nutrition specialists as is likely ever to be gathered together in one place.

The articles are arranged in logical sequence, starting with the soil and the availability of nutrients therein, then passing to the mechanism of entry of mineral nutrients into and their translocation within the plant, leading to the role of minerals and to the disturbances in metabolism resulting from mineral deficiencies. The introductory article, by Kellogg and Orvedal, presents the thesis that, given the proper application of existing knowledge of soil science and the intensification of research where necessary, the extent to which the food-producing capacity of the world can be increased is practically unlimited. Articles of a specialist nature follow, including a particularly lucid discussion by Burström of the mechanism of ion absorption, and a clear exposition by Jenny of the contact theory of mineral uptake. Papers of an applied nature are provided by Boynton and Hester, relating respectively to the cultivation of the apple and of the tomato and other vegetables used in the canning and soup-manufacturing indus- tries. The second of these is of particular interest, not only on account of the array of statistics, such as that the United States tomato crop takes eighteen tons of zine from the soil annually, but also because of the instance which it provides of the rapid and successful application of academic research results to the commercial cultivation of crops.

There is inevitably a risk of repetition in a composite volume of this type, and in fact the Lundegardh theory of active ion absorption receives the consideration of three different authors. A good deal of what is contained in the book was already in print elsewhere, adequate references being in most cases provided; but it is undoubtedly advantageous to have all this information, relating as it does to intimately connected but, for administrative reasons, often quite separately pursued fields of inquiry, assembled together within one cover-for the first time, so far as I am aware.

The book will make a very useful addition to the libraries of those concerned with soil science, plant nutrition and cell physiology. This felicitous arrangement whereby the University of Wisconsin marks its own centenary by an act of signal assistance to those engaged in the study of the plant in relation to the soil is in keeping with the well-established traditions of the University.

G. Bonn

\section{PSYCHICAL RESEARCH DISSECTED}

\section{The Psychology of the Occult}

By D. H. Rawcliffe. Pp. iv $+551+11$ plates. (London: Derricke Ridgway Publishing Co., Ltd., 1952.) 21 s. net.

7 HIS stimulating and highly provocative book is an attempt to describe and analyse the part "played by various types of psychological anomaly in the creation and perpetuation of occult beliefs and practices". The author has cast his net wide and deals briefly with a large number of subjects ranging from lycanthropy to $P K$ (psychokinesis). Following in the tradition of the late Ivor Tuckett (1911), the aurs "Dreimännerbuch" (1925), and more recently Joseph Rinn and Johann Kruse, Mr. Rawcliffe is completely unmoved by the flood of modern propaganda in favour of the reality of so-called psychic phenomena. Even the evidence for mental phenomena such as telepathy and clairvoyance leaves him cold. "There is not even a prima facie case," he writes (p. 21), "for the existence of "psiphenomena', judged from the scientific standpoint." As for the physical phenomena of the séance room, Mr. Rawcliffe finds the evidence scarcely worth considering. To him the whole of the studies of the psychical research worker are mere examples of magic and superstition dressed up in modern garb and often presented behind a façade of statistical jargon which is intended to disguise the faulty character of the original data.

In support of his position he has skilfully put together a mass of material in which the incompetence and credulity of not a few workers in this field are cruelly displayed. Yet he has omitted much that would have strengthened his case and, it must be added, a good deal that would have weakened it. It is clear that he is of the opinion that an explanation of all parapsychological phenomena is to be sought in facts already known, and that there is no need whatever to invoke anything "psychic", which, in 